\title{
Uznemiravanje žena na javnim mjestima - osvrt na uzroke, oblike $i$ učestalost problema uznemiravanja u Hrvatskoj i svijetu
}

\section{Martina Horvat}

Doktorski studij socijalne politike, Studijski centar socijalnog rada Pravnog fakulteta Sveučilišta u Zagrebu, Zagreb, Hrvatska e-mail:martinahorvat1981@yahoo.com

\section{Barbara Perasović Cigrovski}

Doktorski studij socijalne politike, Studijski centar socijalnog rada Pravnog fakulteta Sveučilišta u Zagrebu, Zagreb, Hrvatska e-mail:perasovic@gmail.com

\begin{abstract}
SAŽETAK Rad se bavi objašnjenjem problema uznemiravanja žena na javnim mjestima kao što su ulice, parkovi i druge javne površine te sredstva javnog prijevoza. U svijetu jača znanstveni i aktivistički interes za ovaj problem, ali on i dalje nije dovoljno istražen. Međutim, postojeća istraživanja u Hrvatskoj i svijetu koja se bave ovom temom pokazuju da je veliki broj žena doživio neki oblik uznemiravanja na javnom mjestu. Prvi cilj rada je imenovati, definirati i opisati fenomen uznemiravanja te prikazati etiologiju, fenomenologiju i posljedice uznemiravanja žena na javnim mjestima. Drugi cilj je ukazati na pregled postojećih istraživanja o raširenosti pojave te njenoj prisutnosti u Hrvatskoj i u drugim zemljama. U radu su uz prikaz istraživanja o učestalosti uznemiravanja žena na javnim mjestima, objašnjeni osnovni pojmovi vezani uz uznemiravanje, povezanost s drugim oblicima rodnog nasilja i diskriminacije žena. Uznemiravanje kao dio kontinuuma nasilja nad ženama ostavlja posljedice kako na ženu kao pojedinku tako i na društvo u cjelini te ga je potrebno promatrati kao društveni problem i oblik diskriminacije.
\end{abstract}

Ključne riječi: uznemiravanje žena na javnim mjestima, seksualno i spolno uznemiravanje, rodno nasilje. 


\section{Uvod}

Rad se bavi uznemiravanjem žena na javnim mjestima, kao što su ulice, parkovi i druge javne površine te sredstva javnog prijevoza. Ova je pojava prisutna u različitim zemljama i kulturama koje su usvojile termine kao što su: street harassment u engleskom govornom području, piropos u zemljama Latinske Amerike te eve teasing u Indiji i nekim azijskim zemljama.

U svijetu jača znanstveni, stručni i širi javni interes za ovu temu, no i dalje o njoj nema mnogo znanstvenih članaka te se i dalje nedovoljno sustavno proučava (Fairchild i Rudman, 2008.; Lenton i sur., 1999.). Ilustracije radi, do početka 1990-ih samo je nekoliko istraživača pisalo o uznemiravanju u sklopu područja govora, jezika i komunikacije, a provedena su dva sociološka istraživanja: Gardner 1980. te Benard i Schlaffer 1984. godine (prema Bowman, 1993.). Tekstovi vezani uz uznemiravanje uglavnom analiziraju spolno uznemiravanje u radnom okruženju i slične oblike uznemiravanja i nasilja zlouporabom položaja (Fairchild i Rudman, 2008.; Lenton i sur., 1999.). I u hrvatskoj se znanstvenoj i stručnoj javnosti o uznemiravanju žena na javnim mjestima malo govori i piše. Kroz hrvatske propise i rad Pravobraniteljice za ravnopravnost spolova možemo vidjeti primarno prepoznavanje problema spolnog uznemiravanja na radnom mjestu i u obrazovnom procesu.

Lenton i sur. (1999.) navode dva razloga slabijeg interesa za bavljenje temom: 1) na javnim mjestima uznemiravanje nije ilegalno ako se ne radi o napadu, može se čak interpretirati kao trivijalno ili kao kompliment; 2) javna su mjesta mjesta slučajnog prolaza i ne podliježu jednako strogim normama ponašanja kao formalnija mjesta, npr. radna mjesta ili obrazovne ustanove.

Uznemiravanje žena na javnim mjestima često se trivijalizira ili smatra neizbježnim dijelom javnog života, pa tako Gardner zaključuje (1995.:4): „Žene [...] trenutno doživljavaju uvrede, uporno slijeđenje, štipkanje i diranje od nepoznatih muškaraca i poprilično su sigurne da nitko, niti uznemiravatelj, a vjerojatno niti službena osoba, neće smatrati da se dogodilo nešto vrijedno spomena“. Međutim feministički orijentirane autorice, primjerice Bowman (1993.) i Gardner (1995.), objašnjavaju da je uznemiravanje žena na javnim mjestima diskriminirajuće ponašanje koje umanjuje osjećaj sigurnosti te onemogućava punopravnu društvenu participaciju žena, čime značajno doprinosi širem društvenom problemu neravnopravnosti i diskriminacije žena.

Prvi je cilj ovog rada imenovati i opisati fenomen uznemiravanja žena na javnim mjestima. Započet ćemo definicijom uznemiravanja i srodnih pojmova. Rad će se zatim baviti prikazom etiologije i fenomenologije uznemiravanja, što uključuje pregled postojećih istraživanja o raširenosti uznemiravanja žena na javnim mjestima kao i drugih dosada poznatih činjenica o uznemiravanju na javnim mjestima, kao što su posljedice koje uznemiravanje ostavlja na one žene koje ga dožive te opis počinitelja ili mjesta na kojima se uznemiravanje najčešće događa.

Drugi je cilj prikazati kako je uznemiravanje žena na javnim mjestima raširena pojava kako u Hrvatskoj tako i drugim zemljama svijeta te kako je riječ o problemu koji 
je dio kontinuuma diskriminacije i nasilja nad ženama. Osvrnut ćemo se na postojeću literaturu i podatke o uznemiravanju žena.

Imenovanjem fenomena, smještanjem uznemiravanja žena na javnim mjestima u kontekst nasilja nad ženama te pregledom posljedica koje ostavlja na žene bit ćemo korak bliže prepoznavanju te pojave kao društvenog problema i promišljanju o strategijama prevencije i suzbijanja uznemiravanja.

\section{Definiranje uznemiravanja i srodnih pojmova}

Sam pojam uznemiravanja žena na javnim mjestima obuhvaća širok raspon ponašanja i ostavlja prostora za različita tumačenja. U pojedinim slučajevima ne priznaje mu se epitet nasilja, već se trivijalizira kao da je riječ o prijateljskom ophođenju, komplimentu, flertu i slično. Različite definicije koje ćemo u nastavku razmotriti stavljaju uznemiravanje žena u širi kontekst seksualnog i rodnog nasilja. U Hrvatskoj se udomaćio termin „nasilje nad ženama“ za različita nasilna ponašanja prema ženama, od obiteljskog i partnerskog nasilja do seksualnih napada. Međutim u upotrebi su i drugi termini koje ćemo u nastavku prikazati.

Rodno (uvjetovano) nasilje, na engleskom jeziku gender (based) violence, preciznije označava da u korijenu nasilja leži rod osobe. Dok se pojam spol odnosi na biološka obilježja (spolne organe i sekundarna spolna obilježja), pojam se roda odnosi na društvenu kategoriju. Rod je društveno prihvatljiv izraz spola koji se očituje kroz rodne uloge, norme i ponašanja. Od međuodnosa spola i roda te promjenjivosti definicije roda u vremenu i prostoru polaze postojeći okviri i teorije (većinom feminističke teorije i teorije patrijarhata) koje govore kako su oblici društvene interakcije, kao što je nasilje nad ženama, dominantno odraz roda, dakle društveno su utemeljeni. Rodno se uvjetovano nasilje u Pojmovniku rodne terminologije prema standardima Europske unije (Borić, 2007.) opisuje kao krovni pojam za razne oblike nasilja i uznemiravanja do kojih dolazi zbog društveno određenih rodnih uloga. Rodno nasilje obuhvaća i nasilje prema transrodnim te osobama homoseksualne i biseksualne orijentacije, odnosno nasilje zbog izgleda koji odudara od rodnih stereotipa. Primjer razlikovanja uznemiravanja homoseksualnih i heteroseksualnih žena navodi Di Leonardo (1981.) kada primjećuje kako uznemiravanje lezbijki nikada ne dolazi uz komplimente i nema naizgled prijateljsku interakciju kao što to može biti slučaj kod uznemiravanja heteroseksualnih žena. Iako pojedini oblici rodnog nasilja dijele neke zajedničke karakteristike, kod nasilja prema osobama drugih seksualnih orijentacija moraju se razmotriti dodatne specifične okolnosti i etiologija, kao što su npr. homofobija i zločin iz mržnje, što prelazi opseg ovog rada.

Seksualno nasilje, na engleskom jeziku sexual violence, definirano je kao bilo koji seksualni čin, pokušaj ostvarivanja seksualnog čina, neželjeni seksualni komentar ili prijedlog koji je usmjeren protiv osobe i njezine seksualnosti (Borić, 2007.). Karakterizira ga upotreba sile, prijetnje ili ucjene za ugrožavanje dobrobiti i/ili života žrtve ili njoj bliskih osoba. Ono pokriva brojne vrste seksualnog zlostavljanja među kojima su spolno uznemiravanje, prisilne seksualne radnje, silovanje, incest, seksualno rop- 
stvo, prostitucija, nasilna djela protiv seksualnog integriteta žena, prisilna trudnoća, negiranje prava na korištenje kontracepcije, različite oblike ritualnih praksi, uključujući silovanje u ratu, genitalno sakaćenje žena ili kazne za rodnu transgresiju kao rodno netipičan izgled ili izražavanje (Mamula i Komarić, 2005., prema Borić, 2007.).

Pojmovi uznemiravanja i spolnog uznemiravanja definirani su u zakonima Republike Hrvatske te se navodi da oni predstavljaju oblik diskriminacije. Zakon o suzbijanju diskriminacije (NN 85/08) u članku 3. i Zakon o ravnopravnosti spolova (NN 82/08) u članku 8. definiraju uznemiravanje kao svako neželjeno ponašanje koje ima za cilj ili stvarno predstavlja povredu dostojanstva osobe te koje uzrokuje strah, neprijateljsko, ponižavajuće ili uvredljivo okruženje, a može biti različito iskazano, npr. verbalno ili fizički. Razlika je ta što se Zakon o ravnopravnosti spolova (NN 82/08) usmjerava na uznemiravajuća ponašanja uvjetovana spolom osobe, koja predstavljaju spolno uznemiravanje, dok se Zakon o suzbijanju diskriminacije (NN 85/08) odnosi na neželjena ponašanja po različitim osnovama. Spolno uznemiravanje prema Pojmovniku rodne terminologije prema standardima Europske unije ne mora se odnositi jedino na neželjeni tjelesni dodir, već uključuje dobacivanje, zurenje, praćenje, telefoniranje, neukusne šale ili pozive koji sadrže seksualne konotacije. Mogu mu biti izloženi i muškarci i žene, ali u velikoj većini slučajeva muškarci uznemiruju žene te je spolno uznemiravanje dio nasilja nad ženama koje se događa u cijelom društvu na individualnoj, organiziranoj i institucionalnoj razini (Borić, 2007.:89). Potrebno je primijetiti da se u provedbi Zakona o suzbijanju diskriminacije i Zakona o ravnopravnosti spolova Pravobraniteljica za ravnopravnost spolova u svom dosadašnjem radu usmjerava na slučajeve spolnog uznemiravanja na radnom mjestu i u obrazovnim ustanovama (Izvješća Pravobraniteljice za ravnopravnost spolova iz 2009., 2010. i 2011. godine). Novi Kazneni zakon koji je stupio na snagu 2013. godine u članku 156. po prvi put predviđa spolno uznemiravanje kao kazneno djelo. Definicija spolnog uznemiravanja sukladna je onoj iz Zakona o ravnopravnosti spolova, s tim da bi se ostvarila obilježja kaznenog djela, onaj tko uznemirava mora biti nadređen ili uznemiravati posebno ranjivu osobu ili osobu koja je u odnosu zavisnosti prema njemu (NN 79/13).

Pojam seksualno uznemiravanje istovjetan je spolnom uznemiravanju, samo jasnije ističe usmjerenost počinitelja na ugrožavanje seksualnog integriteta osobe. Obuhvaća neželjena seksualna ponašanja koja mogu, ali i ne moraju uključivati fizički dodir, a osobu dovode u neugodan i ponižavajući položaj te izazivaju osjećaj srama (Borić, 2007.).

Budući da je imenovanje problema početni korak u njihovom prepoznavanju i razumijevanju, u nastavku će biti objašnjen pojam uznemiravanja žena na javnim mjestima.

\subsection{Definiranje pojma uznemiravanja žena na javnim mjestima}

Autorice ovog rada izabrale su se usredotočiti na uznemiravanje žena na javnim mjestima promatrajući taj problem kao oblik diskriminacije i rodno uvjetovanog nasilja koje se događa na javnim mjestima. 
Goffman opisuje javna mjesta kao „sve dijelove zajednice koje su slobodno dostupne svim članovima te zajednice“ (Goffman, 1963.:9, prema Bowman, 1993.:524), pod čime se podrazumijevaju ulice, parkovi, trgovi i sredstva javnog prijevoza, što je definicija koju će i autorice koristiti.

Uznemiravanje žena na javnim mjestima odnosi se na ponašanja koja u hrvatskom jeziku možemo opisati kao seksualno ili spolno uznemiravanje na javnim mjestima, odnosno širok spektar neželjenog ponašanja prema ženama od dobacivanja primjedbi, prijedloga i komentara, verbalnog omalovažavanja kroz uvredljive i diskriminirajuće primjedbe i šale do fizičkih kontakata kao što su približavanje, zaprječivanje prolaza, diranje i hvatanje, izlaganje osobe seksualnim sadržajima, npr. masturbiranje pred njom, praćenje osobe i slična ponašanja koja mogu prerasti uznemiravanje i početi obuhvaćati različite oblike nasilja (Kearl, 2010.). Sam se pojam pojavio u Sjevernoj Americi sedamdesetih godina prošlog stoljeća, a nakon imenovanja problema započela su istraživanja (Lahsaeizadeh i Yousefinejad, 2012., prema Pina i sur., 2009.:127).

Kissling (1991.:453) navodi da su karakteristike uznemiravanja na javnim mjestima sljedeće: „1) cilj uznemiravanja je žena; 2) uznemiravatelj je muškarac; 3) oni se međusobno ne poznaju; te se nalaze 4) na javnom mjestu; 5) licem u lice; 6) interakcija je temeljena na rodu 7) sadržaj interakcije (komentar ili ponašanje) nije namijenjen pokretanju ravnopravne komunikacije“. Zadnja je karakteristika, prema mišljenju autorica ovog teksta, ključna za razlikovanje uznemiravanja od obične socijalne interakcije. Tijekom uznemiravanja upućeni komentari neće ostaviti prostora ili motivirati žene za dijalog (Laniya, 2005.), već će pobuditi osjećaje ljutnje, straha, ili dojam narušavanja privatnosti. Uznemiravatelji se povlače ili postanu agresivni, odnosno nepredvidivo reagiraju ako žena ne prihvati ulogu koju oni od nje očekuju, odnosno ne smiješi se i nije pasivna, već pokaže kako joj se ne sviđa interakcija i želi je prekinuti. Razlikovanje uznemiravanja i prijateljske interakcije ili flerta temelji se upravo na toj okolnosti, može li žena kontrolirati kada će prestati neželjena interakcija (Di Leonardo, 1981.). Žena ne može započeti/prekinuti interakciju na način na koji bi njoj to odgovaralo. Muškarac je taj koji započinje interakciju koja se, površno gledano, može činiti i prijateljska, ali pritom neki manji, često neverbalni znakovi daju naslutiti da nije, npr. boja glasa, stajanje preblizu ili zurenje (Di Leonardo, 1981.).

Sljedeće dvije definicije opisuju nametanje, odnosno narušavanje privatnosti. Antropologinja Micaela di Leonardo (1981.:51-52) objašnjava kako se „uznemiravanje na javnim mjestima javlja kada se jedan ili više muškaraca obraćaju jednoj ili više žena na javnom mjestu koje nije ženino radno mjesto. Kroz poglede, riječi ili geste muškarac utvrđuje svoje pravo za nametanje, odnosno dobivanje ženine pozornosti, istovremeno je definirajući kao seksualni objekt i prisiljava je na interakciju“. Dvije britanske autorice (Wise i Stanley, 1987., prema Bowman, 1993.:524) daju širu definiciju koja obuhvaća i neželjena upućivanja seksualne prirode kao i svako nametanje muškaraca u „ženine osjećaje, misli, ponašanja, prostor, vrijeme, energiju i tijelo“. Time idu korak dalje, uključujući svako nametanje, a ne samo ono seksualne prirode. U ovom kontekstu zanimljivo je razmotriti tzv. „normu civilne nepažnje“ (civil inattention) koju opisuje Bowman (1993.) i koja se odnosi na to da se obično 
u većim gradovima stranci ne gledaju niti se obraćaju jedni drugima na javnim mjestima, što uznemiravatelji krše i na taj način izazivaju neugodu uznemiravanoj osobi. Autorica dalje zaključuje kako se uznemiravanje koristi da se žene „vrati na njihovo mjesto" budući da izlaženjem van u javne prostore odbacuju svoju rodnu ulogu po kojoj bi trebale ostajati u privatnom prostoru (Bowman, 1993.). Isto potvrđuje i studija o uznemiravanju žena u Iranu (Lahsaeizadeh i Yousefinejad, 2012.).

U engleskom govornom području spolno i seksualno uznemiravanje većinom je istraživano i opisivano u sklopu istraživanja uznemiravanja na radnim mjestima i u obrazovnim institucijama, pri čemu engleski termin sexual harrassment obuhvaća hrvatske termine seksualnog i spolnog uznemiravanja. Obično se razlikuju tri skupine uznemiravajućih ponašanja: seksualna prisila (direktno upućen zahtjev za seksualnim činom kako bi se na poslu ili školi/fakultetu napredovalo, npr. u vidu promaknuća ili bolje ocjene), rodno uznemiravanje (omalovažavanje žena kao društvene skupine, npr. zbijanje šala o ženama kao seksualnim objektima) te neželjena seksualna pažnja (omalovažavanje na individualnoj razini i tretiranje žena kao seksualnih objekata slanjem neukusnih mailova, diranjem ili zurenjem) (Gelfand, Fitzgerald i Drasgow, 1995., prema Fairchild i Rudman, 2008.). Fairchild i Rudman (2008.) primjećuju kako je uznemiravanje na javnim mjestima vrlo srodno opisanoj trećoj skupini seksualnog uznemiravanja na radnom mjestu ili obrazovnoj ustanovi, no upozoravaju kako i uznemiravanje od neznanaca i uznemiravanje od poznatih osoba ima svoje specifičnosti kojima se u postojećim istraživanjima posvećuje nedovoljna pažnja.

\subsection{Tko su uznemiravatelji i koga uznemiravaju}

Iako se uznemiravanje može dogoditi osobama obaju rodova, iskustva žena, istraživanja i statistike govore o „nadzastupljenosti“ ženskoga roda među uznemiravanima i onima nad kojim se čini nasilje (Borić, 2007.:82). Zanimljivo je napomenuti da se u engleskom govornom području uvriježio termin street harassment, u prijevodu „ulično uznemiravanje“, bez rodnog predznaka jer se rodna dimenzija sama po sebi podrazumijeva (Kearl, 2010., Laniya, 2005.; Bowman, 1993.; ihollaback.org; stopstreetharassment.org).

Uz problem uznemiravanja žena na javnim mjestima često se povezuju jednaka pogrešna uvjerenja kao i uz druge oblike rodnog nasilja. Česti su stereotipi o određenim tipovima nasilnika. Jedan je mit da muškarci nižeg socioekonomskog statusa češce uznemiravaju. Što se znanstvene opravdanosti ovakve tvrdnje tiče, dio istraživanja ne pronalazi nikakve razlike u socioekonomskom statusu uznemiravatelja te potvrđuje da uznemiravatelji dolaze iz svih socioekonomskih i obrazovnih slojeva kao i iz svih dijelova svijeta (Benard i Schlaffer, 1984., prema Laniya, 2005.; Gardner, 1995.; Kearl, 2010.). Prema istraživanju uznemiravanja žena provedenom u Iranu (Lahsaeizadeh i Yousefinejad, 2012.), ispitanice su kroz dubinske intervjue potvrdile da uznemiravatelji dolaze iz svih društvenih slojeva, no uznemiravanje muškaraca nižeg socijalno-ekonomskog statusa opisale su više ugrožavajućim jer oni češće slijede žene i dodiruju ih. Druga istraživanja objašnjavaju da je razlog što je veći broj pre- 
poznatih uznemiravatelja nižeg socioekonomskog statusa, točnije radničke klase, taj što je njihovo radno mjesto češće na javnom mjestu ili što će se njih lakše primijetiti (Kissling, 1991.). Prema Di Leonardo (1981.), muškarci uznemiravanjem jačaju svoj status, npr. radnici na gradilištu ili vozači taksija/kamiona, koji je inače unutar društvenog poretka vrlo nizak. Općenito prema autorici (Di Leonardo, 1981.), muškarci gube svoj status, odnosno mogućnost dominacije kroz promjenu životnog stila žena (većinom kroz ulazak na tržište rada). Lenton i sur. (1999.) na reprezentativnom su uzorku žena u Kanadi dobili jedan od rijetkih uvida u sociodemografske karakteristike žrtava: veća učestalost uznemiravanja nađena je kod nezaposlenih žena te mlađih žena i žena bez partnera.

\section{Etiologija uznemiravanja žena na javnim mjestima}

Postoji više teorijskih pristupa koji različito objašnjavaju etiologiju nasilnih ili kažnjivih ponašanja, te će neka od ovih objašnjenja biti primjenjiva i na objašnjavanje uznemiravanja žena na javnim mjestima. Razlikuju se pristupi usmjereni na istraživanje karakteristika samog uznemiravatelja ili žrtve koji se bave biološkim, psihološkim ili okolinskim uvjetima, kao što su odgoj, obiteljski, prijateljski ili radni odnosi, od pristupa koji se usmjeravaju na objašnjenje širih društvenih utjecaja koji potiču ili omogućavaju uznemiravanje.

Tradicionalna objašnjenja uzroka uznemiravanja i nasilja pozornost često usmjeravaju na žrtvu i na ono što je u izgledu ili ponašanju žrtve moglo potaknuti reakciju počinitelja te se žrtve često savjetuje kako mogu neželjeno ponašanje pokušati izbjeći. Američka aktivistkinja Kearl opisuje kako su žene u različitim kulturama odgajane uz savjete i upozorenja o tome kako izbjeći spolno uznemiravanje i nasilje: „Savjeti naših baka i mama odnosili su se na to da se ne oblačimo provokativno, da se ne krećemo same noću po ulicama, da izbjegavamo parkove dok smo same i slično." (Kearl, 2010.). U mnogim se kulturama ženama ograničavalo kretanje kako bi se spriječilo seksualno nasilje i uznemiravanje. Međutim, čak i ukoliko priznamo dobronamjernost ovih strategija izbjegavanja, one niti su djelotvorne niti su provedive u društvu u kojem se očekuje puna participacija žena. Uz izgled žrtve ponekad se kao rizični čimbenici za seksualno uznemiravanje spominju mlađa životna dob te iskustvo viktimizacije, odnosno seksualnog zlostavljanja (Parish, Das i Laumann, 2006.).

Teorije racionalnog izbora kriminološke su teorije koje polaze od pretpostavke da su počinitelji bilo kojeg nasilnog ili kažnjivog djela racionalna bića te da odlučuju o svom ponašanju temeljem procjene rizika i korisnosti koju bi izbor određenog ponašanja imao za njih same. Ovaj model omogućava dodatne hipoteze o uznemiravanju uz objašnjenje rizičnih čimbenika koji utječu na povećanje vjerojatnosti uznemiravanja, i to osobito one vezane uz žrtvu i okolnosti situacije. Primjenom ove teorije možemo zaključiti da će počinitelj uznemiravati ako postoji prilika, odnosno mogućnost za to, a pri tome će se u izboru ponašanja ravnati time kolika je privlačnost cilja i kolika je cijena tog čina, odnosno mogućim posljedicama i sankcijama (Clarke i Felson, 1993.; Cohen i Felson, 1979.; Cohen i sur., 1981., prema Parish i sur., 2006.). Prema tome, dok god je uznemiravanje žena na javnim mjestima pona- 
šanje bez posljedica, ono počiniteljima može biti primamljivo. Postavlja se pitanje kako bi mogućnost neželjene posljedice, kao što je pomoć drugih ljudi žrtvi ili pravno sankcioniranje seksualnog uznemiravanja, utjecali na počinitelja. Dodatno je pitanje kako promatrači mogu svojim reakcijama utjecati na počinitelja da prestane koristiti spolno uznemiravajuća ponašanja. U tom smislu neki istraživači naglašavaju da je žena koja nema zaštitu u većem riziku od uznemiravanja, a rizični čimbenik za uznemiravanje može biti i život u velikom mjestu u kojem je slaba kohezija u zajednici jer je time manja mogućnost socijalnih pritisaka na uznemiravatelja (Del Frate i sur. 2002., prema Parish i sur., 2006.).

Na razini društvenih zajednica potvrđeno je da je veća vjerojatnost uznemiravanja u zajednicama u kojima su jaki stereotipi o rodnim ulogama, a manja je vjerojatnost uznemiravanja ukoliko je uznemiravanje podložno sankcijama (Choi, 1993.; De Judicibus i McCabe, 2001.; O'Connell i Korabik, 2000.; O'Hare i O'Donohue, 1998.; Salzinger, 2000.; Welsh, 1999., prema Parish i sur., 2006.).

U okviru teorije racionalnog izbora istraživalo se na koji su način izgled i ponašanje potencijalne žrtve utjecali na uznemiravatelja. Neki autori ističu kako osobito u tranzicijskim društvima, u kojima se događaju brojne promjene vezane uz odijevanje žena i odnose među spolovima, muškarci mogu način odijevanja i ponašanja pojedinih žena tumačiti kao opravdanje za uznemiravanje (Parish i sur., 2006.). Dodatni argument za ovakav stav daju istraživanja koja pokazuju da su muškarci značajno skloniji od žena svakodnevnoj interakciji pridavati seksualne konotacije (Johnson i sur., 1991.; Stockdale, 1993., prema Parish i sur., 2006.).

Feminističke teorije nastoje propitati društvene uloge i identitet žene, objasniti zašto se muškarci češće kažnjivo ponašaju, zašto su žene češće žrtve te nastoje propitati jesu li i u kojoj mjeri tradicionalne teorije koje su stvorili muškarci i koje primarno u centar stavljaju muško iskustvo primjenjive i za objašnjavanje ženskog iskustva. Feministički pristup razlike u moći muško uznemiravanje i općenito nasilje nad ženama objašnjava patrijarhalnim normama i razlikom u moći između muškaraca i žena. U Pojmovniku rodne terminologije prema standardima Europske unije navodi se da iz diskriminirajućeg položaja žena u društvu i nejednake distribucije moći proizlazi i pojačan rizik od viktimizacije žena u različitim sustavima, od obitelji do ulice i javnih mjesta (Borić, 2007.:97). Patrijarhalna moć očituje se u podčinjavanju, kontroliranju i ponižavanju žene u svim područjima života, posebno u sferi tjelesnosti i seksualnosti. Spolno je uznemiravanje jedan od oblika pokazivanja dominacije, autoriteta i moći nad drugom osobom i često se događa u institucijama kao što su škola, fakultet ili radno mjesto, ali i u široj javnosti, poput medija i umjetnosti. I kod uznemiravanja žena na javnim mjestima problem je u dominaciji jednog roda nad drugim, a ne u seksualnosti i nemogućnosti kontrole seksualnog nagona muškaraca. Benard i Schlaffer (1984., prema Laniya, 2005.) u svojoj su studiji dobili podatak da otprilike 20\% muškaraca uznemiruje samo u prisutnosti drugih muškaraca. Objašnjenje je autorica studije da time utvrđuju grupni identitet, odnosno identitet muškog roda kao dominantnog. Autori Berdahl, Magley i Waldo (1996.); Benard i Schlaffer (1997.); Choi, Au, Cheng, Tang i Yik (1993.); Cleveland i Kerst (1993.); O`Connell i Korabik (2000.) te Wilson i Thompson (2001.) istražujući uznemiravanje žena u radnom okruženju nalaze da vjerojatnost uznemiravanja povećava razlike u moći, bilo one koje 
proizlaze iz društvenih normi, organizacijske hijerarhije ili međuljudskih obilježja (prema Parish i sur., 2006.). Prema hipotezi koja je posebno primjenjiva na uznemiravanje na javnim mjestima, žene koje krše tradicionalne norme odijevanja ili ponašanja kažnjavaju se verbalnim uznemiravanjem, i to osobito u tranzicijskim društvima (Parish, i sur., 2006.). Ulično uznemiravanje žena srednje klase u Londonu u 19. stoljeću, koje opisuje Walkowitz (1998.), primjer je takvog oblika uznemiravanja jer su žene bile izložene verbalnom uznemiravanju ukoliko bi hodale ulicama same bez muške pratnje, čime su prekršile tradicionalnu normu toga vremena. Drugi je primjer studija u Iranu (Lahsaeizadeh i Yousefinejad, 2012.) koja je potvrdila kako su žene koje se šminkaju i manje tradicionalno oblače izloženije uznemiravanju kao obliku kažnjavanja za odstupanje od rodnih normi o primjerenom izgledu i odijevanju.

Lenton i sur. (1999.:519-520) među rijetkima pokušavaju dati odgovore upravo o uzrocima uznemiravanja na javnim mjestima. Njihova studija metodološki ne omogućava pronalaženje uzročno-posljedičnih veza, no ipak uz pomoć korelacija iskustva uznemiravanja i demografskih varijabli pokušavaju barem započeti raspravu u tom smjeru te navode tri argumenta kao tri podskupine feminističkih pristupa:

1. socijalno-strukturalni argument: glavni je uzrok društvena moć te se argumentira kako su, uz žene, i druge skupine s manje moći više podložne uznemiravanju

2. socijalno-kulturalni argument: objašnjava uznemiravanje kroz izgradnju i održavanje rodnih uloga i normi, kao što su norma muške seksualnosti (erotizira se muška agresija, žene se predstavlja kao seksualne objekte) i uloga žena u privatnoj sferi. Kodeks ponašanja na javnim mjestima odražava te norme, te muškarci dokazuju svoju seksualnost, a za žene se očekuje da se kreću u društvu i da ne privlače pažnju na sebe. Sukladno tomu, žene koje uznemiravanje vide kao veći društveni problem (Stockdale i sur., 1995., prema Lenton i sur., 1999.:520; Gardner, 1995.) ili su feministički orijentirane (Brooks i Perot, 1991., prema Lenton i sur., 1999.:520) prije će vjerovati da je uznemiravanje prekršilo norme

3. argument socijalne kontrole: uznemiravanje služi kako bi se održao status quo muške dominacije. Tako će muškarci koji povezuju seksualnost s muškom dominacijom imati više bodova na skali vjerojatnosti seksualnog uznemiravanja (Pryor, Giedd i Williams, 1995., prema Lenton i sur., 1999.:520).

Veća učestalost uznemiravanja žena koje nemaju partnera i koje su mlađe može se objasniti kroz strukturalni i kulturalni argument: one mogu imati niži status ili predstavljati skupine žena kojima društvene norme pripisuju veću seksualiziranost, a moguće je da se one češće kreću same ili u društvu drugih žena, bez pratnje muškaraca. Posljedice kao i reakcije žena na uznemiravanje mogu se objasniti argumentom socijalne kontrole: žene često osjećaju strah te ograničavaju svoje aktivnosti na javnim mjestima.

\section{Fenomenološka istraživanja rasprostranjenosti i učestalosti uznemiravanja žena}

Uznemiravanje žena na javnim mjestima problem je koji je tek u novije vrijeme pobudio znanstveno-istraživački interes, međutim ne znači da u prošlosti nije postojao. 
Postoje stariji podaci o uznemiravanju žena na javnim mjestima (Bowman, 1993.), koji se u velikoj mjeri oslanjanju na iskustvo žena i neznanstvene izvore, poput ženskih časopisa i blogova. Bowman (1993.) je našla izvještaje koji govore o uznemiravanju u 19. stoljeću te je zaključila da je opis događaja iz tog vremena vrlo sličan iskustvima žena današnjice. Zanimljiv je antropološko-povijesni opis uznemiravanja na ulicama Londona u drugoj polovici 19. stoljeća autorice Walkowitz (1998.). U toj studiji daje se pregled članaka u popularnim časopisima gdje novinari i čitatelji pišu o uličnom uznemiravanju, koje je pod utjecajem društvenih promjena i većeg izlaska žena na javna mjesta postalo vrlo aktualno. Teme koje se javljaju vrlo su slične današnjim mitovima o rodno uvjetovanom nasilju. Tako se okrivljavaju žene da su izazvale uznemiravanje svojim načinom oblačenja ili kasnim izlascima te se kao tipične uznemiravatelje navodi radnike ili osobe nižeg socioekonomskog statusa. Muškarci na iskustva žena odgovaraju opravdavanjem svoga ponašanja kao flerta navodeći da feministkinje kao pripadnice više klase krivo interpretiraju flert koji se javio u rastućoj srednjoj klasi. Nakon toga duže vrijeme pojava nije izazivala istraživački interes. Međutim postojale su neke metode usmjerene na osiguravanje veće razine sigurnosti žena, kao što su anti flirt klubovi 20-ih godina prošloga stoljeća (McEwen, 2013.). S buđenjem ženskog pokreta 70-ih i 80-ih godina prošloga stoljeća češće se pojavljuju i iskustva uznemiravanja ispričana iz prvog lica (Di Leonardo, 1981.). Bowman (1993.) i Di Leonardo (1981.) pretpostavljaju kako je uznemiravanje u tim dvama desetljećima postalo učestalije, ali i uvredljivije. Žene su u tim razdobljima počele biti sve češće prisutne na javnim mjestima bez pratnje muškaraca ili djece zbog društvenih promjena koje su nastupile: više zaposlenih žena, kasnije stupanje u brak i više stope razvoda, češće bavljenje slobodnim aktivnostima na otvorenom. Opisano je da periodi recesije i nezaposlenosti mogu povećati uznemiravanje jednostavno zato što je više muškaraca prisutno na ulicama.

Kvalitativna ili kvantitativna istraživanja o uznemiravanju žena na javnim mjestima nisu tako brojna te se teško mogu uspoređivati zbog različite definicije uznemiravanja, različite metodologije ili čak nepotpunih podataka o korištenoj metodologiji. Od svih istraživanja na koje smo naišle pretražujući internacionalne i nacionalne baze istraživanja, dva su provedena na nacionalno reprezentativnom uzorku. Macmillan i sur. (2000.) analizirali su podatke nacionalne studije o nasilju nad ženama koja je provedena 1993. godine na uzorku od 12,300 žena starijih od 18 godina te utvrdili kako je $85 \%$ ispitanica doživjelo uznemiravanje od neznanaca, od čega je najveći broj doživjelo neželjenu pažnju kao što je zurenje ili dobacivanje. Istraživanje Lentona i sur. (1999.), koje je također provedeno u Kanadi 1992. godine na uzorku od 1990 žena u dobi od 18 - 65 godina, govori o sličnim podacima: 91\% žena navelo je barem jedan oblik uznemiravanja, a 77\% je navelo više od jednog oblika. Ostala istraživanja obuhvaćaju online ankete u kojima uzorkovanje većinom nije detaljno opisano, no iz opisa se može pretpostaviti da je uzorak bio prigodni ili namjerni ili se radilo o anketiranju studenata te kvalitativnim metodama poput dubinskih intervjua. Međutim sva dostupna istraživanja govore da je problem uznemiravanja žena vrlo raširen. Ovisno o obliku uznemiravanja, pojedine studije navode učestalost veću od 90\%. U online istraživanju (Kearl, 2010.) koje je obuhvatilo 811 žena putem online ankete učestalost je uznemiravanja na javnim mjestima iznosila 99\%, dok je u dubinskim intervjuima s 293 žene iznosila 97\% (Gardner, 1995.). Prema online 
anketi provedenoj u Turskoj na 141 ispitanika, među njima 91\% žena, najčešći su doživljeni oblici uznemiravanja zurenje (75\%), trubljenje (60\%), zviždanje (59\%), zvukovi poljubaca (48\%) te dodirivanje na seksualan način (46\%) (Hunter, 2012.). U Poljskoj (Roszak i Gober, 2012.) je provedena online anketa koja je uključivala 818 muškaraca i žena, s time da su 86\% uzorka činile žene. $85 \%$ žena i 44\% muškaraca doživjelo je uznemiravanje na javnim mjestima, 78\% svih uznemiravatelja su muškarci, a srednja je dob prvog iskustva 12 godina. Kearl (2010.) također navodi kako uznemiravanje kreće od vrlo rane dobi: $87 \%$ ispitanica doživjelo je uznemiravanje do devetnaeste godine, od čega $22 \%$ do svoje dvanaeste i $66 \%$ do petnaeste godine. Istraživanja govore o tome da se neki oblici uznemiravanja događaju često ili redovito. Primjerice, na uzorku od 228 studentica u SAD-u (Fairchild i Rudman 2008.) 32\% studentica doživjelo je zazivanje, zviždanje ili zurenje jednom mjesečno, 33\% dvaput mjesečno i 31\% svakih par dana ili češće.

Iz predstavljenih je istraživanja vidljivo da uznemiravanje na javnim mjestima obuhvaća vrlo širok raspon ponašanja, a operacionalizacija i uzorkovanje predstavljaju teškoću u usporedbi istraživanja. Bez obzira na nedostatke istraživanja, navedeni podaci dovoljna su naznaka da ovom fenomenu treba pokloniti veću istraživačku pažnju, ali i poduzeti mjere prevencije i suzbijanja. Također daju uvid u daljnja istraŽivačka pitanja poput geografske rasprostranjenosti, u kojoj je javlja uznemiravanje i dr. Istraživanja pokazuju kako je fenomen prisutan u različitim zemljama i kulturama. Više od 80\% žena u istraživanjima provedenima u Egiptu i Kanadi navode da su doživjele spolno uznemiravanje na javnim mjestima (Kearl, 2010.). U Jemenu je ta brojka viša od 90\%, iako se u toj zemlji definitivno opovrgava mit da su žene to nasilje same izazvale svojim provokativnim odijevanjem, budući da se većina žena u Jemenu djelomično ili potpuno pokriva (Kearl, 2010.). Prema nacionalnoj statistici o kriminalitetu, u Indiji je više od 11,000 žena podnijelo pritužbu da su doživjele seksualno uznemiravanje u 2009. i 2010. godini. Podaci se odnose samo na službene pritužbe, dok se smatra da većina žena ignorira nasilje na ulicama i zbog toga ne traži policijsku pomoć (Sarkar, 2011.). Neki autori smatraju da je uznemiravanje žena na javnim mjestima manje prisutno u fundamentalističkim režimima u kojima su žene rijetko viđene u javnosti (Evans, 1985., prema Bowman, 1993.), ali iranska studija na reprezentativnom uzorku studentica na Sveučilištu u Shirazu pokazuje da je uznemiravanje žena prisutno i u njihovom društvu, prevalencija se kreće od 64\% (uvredljivi komentari) do 97\% (zurenje) (Lahsaeizadeh i Yousefinejad, 2012.).

Uznemiravanje na javnim mjestima uobičajeno je u urbanim dijelovima (Bowman, 1993.; Kearl, 2010.), a slabije je prisutno u malim mjestima / selima gdje se većina ljudi poznaje. Slabija je prisutnost fenomena u selima očekivana budući da se uznemiravanje na javnim mjestima događa među neznancima (Benard i Schlaffer, 1984., prema Bowman, 1993.) te da cilj interakcije nije prijateljski, već se radi o neželjenim, degradirajućim komentarima ili gestama koje se neće usmjeriti prema poznatima. Prema rezultatima istraživanja provedenog u Iranu (Lahsaeizadeh i Yousefinejad, 2012.), uznemiravanje je češće na mjestima koja su manje nadzirana, poput ulica i parkova (Lahsaeizadeh i Yousefinejad, 2012.). Pojedini autori govore o visokoj učestalosti uznemiravanja u javnom prijevozu te Kearl navodi kako je Tokyo uveo zasebne vlakove podzemne željeznice samo za žene (Kearl, 2010.). Dubinski inter- 
vjui provedeni u Beogradu sa 76 žena od 20 do 29 godina u kojima se ispitivalo isključivo uznemiravanje u javnom prijevozu (Tanasković i Račeta, 2007.) pokazali su učestalost od 96\% barem jedanput, a 46\% više od dva puta. Prema online anketi koju je proveo Ured predsjednika okruga Manhattana na uzorku od 1790 ispitanika u kojem oko 2/3 uzorka čine žene, 63\% je uznemiravano, a 10\% je doživjelo seksualni napad u podzemnoj željeznici u New Yorku (Stringer 2007., prema Kearl, 2010.).

Učestalost uznemiravanja na javnim mjestima, prema dostupnim podacima, veća je od uznemiravanja na radnom mjestu ili u obrazovnim ustanovama: U već spomenutoj analizi podataka nacionalne studije o nasilju nad ženama u Kanadi (Macmillan i sur., 2000.) autori su usporedili podatke koji se odnose na uznemiravanje žena od neznanaca i poznatih osoba: $85 \%$ ispitanica doživjelo je uznemiravanje od neznanaca, dok je 51\% doživjelo uznemiravanje od poznatih osoba. Iako pitanja ne obuhvaćaju mjesto na kojem se uznemiravanje događa, ipak možemo zaključiti kako je vjerojatno da je uznemiravanje na javnim mjestima češće nego uznemiravanje na radnom mjestu ili obrazovnoj ustanovi. Istraživanje uznemiravanja na sveučilištu (Lahsaeizadeh i Yousefinejad, 2012.) također je potvrdilo veću učestalost uznemiravanja na javnim mjestima od uznemiravanja na fakultetu.

O uznemiravanju žena na javnim mjestima u Hrvatskoj govore podaci iz Izvješća organizacije Ženska soba prema kojem seksualno nasilje u Hrvatskoj ostaje nevidljivo u velikom broju i često se ne prijavljuje zbog muške institucionalne moći, rasprostranjenih predrasuda o društvenim ulogama i ponašanjima muškaraca i žena te podržavanja predrasude o krivnji žrtve seksualnog nasilja (Mamula, 2006.). Kad se nasilje i prijavi, teško se sudski dokazuje te je žrtva izložena dodatnoj traumi i stigmatizaciji. Prema procjenama udruga što rade sa ženama koje su preživjele seksualno nasilje pa tako i prema procjeni udruge Ženska soba, svaka će treća žena tijekom života doživjeti neki oblik seksualnog nasilja. Vezano specifično uz fenomen uznemiravanja na javnim mjestima, u Hrvatskoj su dostupna samo dva istraživanja. Istraživanje Ženske sobe na uzorku od 1491 žene (Mamula, 2006.) utvrdilo je kako je 55\% žena u Hrvatskoj doživjelo neželjene seksualne primjedbe i vulgarne ponude, a 43\% neželjeno dodirivanje tijela. Na pitanje o mjestu uznemiravanja najčešći odgovori vezani su uz javna mjesta kao što su kafići, ulica, autobusi i tramvaji. Hollaback Hrvatska, hrvatski ogranak internacionalnog pokreta protiv uznemiravanja na javnim mjestima, proveo je online anketu (Perasović Cigrovski, Horvat i Komšić, 2012.). Istraživanje je obuhvatilo 446 žena u dobi od 13 do 74 godina. 99,6\% ispitanica potvrdilo je da je bilo izloženo barem jednom obliku uznemiravanja na javnim mjestima. Iz istraživanja se nameće zaključak kako su manje ugrožavajući oblici, poput zurenja (doživljeno od 94\% žena), neželjenih komentara o izgledu (93\%) ili zviždanja (92\%) češći nego više ugrožavajući, poput uhođenja (53\%), dodirivanja (55\%) ili pak seksualnog napada (32\%). Kao mjesta uznemiravanja navedene su: ulice od $57 \%$ žena, zatim javni prijevoz (17\%) te stanice javnog prijevoza (7\%), a 15\% ispitanica nadodalo je i obrazovnu instituciju ili njezino okružje, iako taj odgovor nije bio predviđen upitnikom. Opisana istraživanja nedovoljna su za procjenu raširenosti uznemiravanja žena na javnim mjestima u Hrvatskoj, no daju naslutiti da je uznemiravanje žena na javnim mjestima rašireno i u našoj zemlji te da postoji potreba za boljim mjerenjem i razumijevanjem te pojave. 


\section{Posljedice uznemiravanja žena na javnim mjestima}

U svrhu dubljeg razumijevanja uznemiravanja kao društvenog problema važno je osvijestiti posljedice uznemiravanja. Bowman (1993.) opisuje posljedice na dvjema razinama: posljedice na žene kao pojedinke i posljedice na društvo u cjelini. Za samu ženu kao pojedinku uznemiravanje je ometanje privatnosti te utječe na: strah od prerastanja uznemiravanja u nasilje i seksualni napad, samo-objektivizaciju žena, negativne psihološke posljedice i negativan utjecaj na samopoštovanje, smanjivanje mobilnosti i negativan utjecaj na ekonomsku situaciju žena. Međutim uznemiravanje ostavlja posljedice i na društvo u cjelini jer utječe na ovisnost žena o muškarcima, strah žena od muškaraca kao i na smanjenu društvenu participaciju žena jer istiskuju žene s javnih mjesta u privatnu sferu te potvrđuje i produbljuje diskriminaciju.

\subsection{Posljedice uznemiravanja na žene kao pojedinke}

Uznemiravanje na javnim mjestima utječe na žene kao pojedinke i više nego što postoji svijest o tome u široj zajednici. Uznemiravane žene često opisuju uznemiravanje kao ometanje privatnosti te opisuju strah od prerastanja uznemiravanja u silovanje ili fizički napad (Gardner, 1980., prema Bowman, 1993.). Istraživanja (Ferraro, 1996.; Fisher i Sloan, 2003, prema Fairchild i Rudman, 2008.) su pokazala da žene imaju veći strah od viktimizacije nego muškarci budući da strah od silovanja određuje njihov strah od drugih napada. Silovanje kao potencijalan ishod drugih viktimizacija je i primaran izvor anksioznosti, a uznemiravanje podsjeća žene na potencijalnu opasnost. Tome u prilog ide nalaz da strah od silovanja dolazi i uz strah od drugih zločina kao što je pljačka (Ferraro, 1996., prema Fairchild i Rudman, 2008.). Lenton i sur. (1999.) u istraživanju provedenom na nacionalno reprezentativnom uzorku od 1990 žena u dobi od 18 do 65 godina u Kanadi pokazali su da vjerojatnost straha od zločina raste u slučaju da je žena prethodno barem jednom u životu doživjela uznemiravanje kao i u slučaju da je doživjela uznemiravanje koje percipira kao više uznemirujuće. Također, ne smijemo zanemariti da ukoliko je žena kojoj se događa uznemiravanje već bila žrtva silovanja ili seksualnog napada, njen će strah prilikom uznemiravanja biti veći i može dovesti do traumatske reakcije.

Uznemiravanje ostavlja negativne psihološke posljedice, koje su utvrđene čak i kada žene same nisu smatrale da su uznemiravane, odnosno nisu neko ponašanje okarakterizirale kao uznemiravanje (Schneider i sur. 1997., prema Fairchild i Rudman, 2008.). Psihološke posljedice ovise i o vrsti uznemiravanja. Prema online istraživanju Kearl (2010.) koje je ispitivalo reakcije žena na interakciju od strane muškaraca na javnim mjestima, većina žena reagira sretno, polaskano ili neutralno na osmijeh, pozdrav ili pričanje o neutralnoj temi kao što je vrijeme, a manje se od 5\% osjeća uplašeno. S druge strane, većina se žena osjeća ljuto kod ponašanja (npr. zviždanja) ili komentara kojima se referira na njihov izgled. Granicu žene svakako povlače kod seksualno eksplicitnih komentara - većina žena se osjeća ljuto, uplašeno i uvrijeđeno, a manje od 1\% žena sretno ili polaskano. Slično se može reći i za zurenje, vulgarne geste, masturbaciju na javnom mjestu, uhođenje ili diranje na seksualan način. 
Teorija samo-objektivizacije (self objectification theory) (Fredricksoni Roberts, 1997., prema Fairchild i Rudman, 2008.) argumentira kako učestalo tretiranje žena kao seksualnih objekata može dovesti do samo-objektivizacije žena koje nastupa kada žene same sebe definiraju kao seksualne objekte, srame se svog tijela te posvećuju stalnu pozornost vanjskom izgledu. Istraživanja pokazuju kako je samo-objektivizacija povezana s negativnim psihološkim posljedicama, uključujući depresiju i poremećaje prehrane (Greenleaf, 2005.; Harrison i Fredrickson, 2003.; Muehlenkamp i Saris-Baglama, 2002.; Muehlenkamp, Swanson i Brausch, 2005.; Slater i Tiggemann, 2002.; Tiggemann i Kuring, 2004.; Tiggemann i Slater, 2001., prema Fairchild i Rudman, 2008.). Kearl (2010.) navodi kako iskustvo uznemiravanja utječe na veću vjerojatnost korištenja različitih zaštitnih strategija, među kojima je i ograničavanje područja kretanja. Povezanost uznemiravanja i ograničavanja kretanja, bilo izravnu ili zbog straha od silovanja, pronalaze i drugi istraživači (Hickman i Muehlenhard, 1997.; Krahe, 2005.; Warr, 1985., prema Fairchild i Rudman, 2008.; Fairchild i Rudman, 2008.; Lenton i sur., 1999.).

Uznemiravanje na javnim mjestima može negativno utjecati na ekonomsku situaciju i poslovni uspjeh žena. Žene mogu izbjegavati zanimanja zbog kojih bi morale raditi na otvorenom kako bi izbjegle uznemiravanje od muških kolega (kojih ima više u takvim zanimanjima) ili neznanaca (Bowman, 1993.). Uznemiravanje na putu do posla ili škole može skrenuti pozornost žena s misli vezanih za profesionalnu ulogu i trenutno im smanjiti samopoštovanje, što utječe i na izvedbu na poslu ili školi (Laniya, 2005.). U online istraživanju $9 \%$ žena navelo je da su promijenile posao barem jednom zbog uznemiravanja na putu do posla (Kearl, 2010.).

\subsection{Posljedice uznemiravanja na društvo u cjelini}

Dok razumijevanje posljedica na žene kao pojedinke može pomoći u smanjenju trivijalizacije ženskog iskustva, bez povezivanja s posljedicama uznemiravanja na društvo ne možemo shvatiti uznemiravanje kao širi društveni problem koji istovremeno opisuje i održava diskriminaciju žena u društvu. Uznemiravanje utječe na ovisnost žena o muškarcima (žene će tražiti mušku pratnju kako bi se osjećale sigurnije) i doprinosi nepovjerenju i neprijateljstvu između rodova (muškarcu koji ima dobre namjere postaje teško obratiti se ženi, te će se morati više potruditi objasniti da je dostojan povjerenja). Seksualno eksplicitni komentari na javnim mjestima uče žene dvama aspektima rodnog identiteta. S jedne strane uče ih objektivizaciji žena kroz podsjećanje na to da ih društvo vrednuje preko njihovog izgleda (Kearl, 2010.), a s druge strane pripadnosti žena privatnoj sferi budući da žene počnu doživljavati da javna mjesta nisu za njih, čime se učvršćuje rodna podjela na javno - privatno te zadržava hijerarhija rodova u svakodnevnom životu (Bowman, 1993.).

\section{Prepoznavanje, prevencija i suzbijanje društvenog problema uznemiravanja žena na javnim mjestima}

Trivijalizacija ženskog iskustva uznemiravanja opisana je unutar feminističke literature. West (2000.:150) navodi da se bolna iskustva koje doživljavaju žene često „za- 
nemaruju kao trivijalne (kao što je uznemiravanje na radnom ili javnom mjestu); kao dobivene s pristankom (seksualno uznemiravanje na poslu); duhovite (nenasilno silovanje u braku); nesvjesno željene ili izazvane od strane žrtve (incest između oca i kćeri); prirodne i biološke, dakle neizbježne (porod); sporadične, konceptualno slične kao i rodno neutralna bol (silovanje koje se gleda isključivo u kontekstu nasilja); zaslužene ili privatne prirode (obiteljsko nasilje); nepostojeće (pornografija); neshvatljive (neugodan seksualni odnos s pristankom) [...]“. Unutar feminističke literature postoje različita objašnjenja zašto te ozljede nisu doživljene kao ozbiljne, a sve kreću od pretpostavke da je percepcija svih doživljaja, tako i onih marginalizirane grupe (žena), određena pogledom na stvarnost dominantne grupe (muškaraca). Za takvu se percepciju navodi više razloga: 1) žene se ne shvaćaju kao ravnopravne u društvu, pa njihova iskustva kao i povrede nisu toliko važne; 2) ne postoji želja za razumijevanjem kod dominantne grupe (muškaraca); 3) ženska iskustva dominantna grupa (muškarci) ni ne može razumjeti jer su i kvalitativno različita (West, 2000.).

Objašnjenje samog procesa transformacije subjektivnih doživljaja u sudske sporove, koja je usporediva s percepcijom potrebe društvene intervencije, može se naći kod autora Felstiner, Abel i Sarat (1980./1981.), a primjenu njegovog okvira na fenomen uznemiravanja iz feminističke perspektive možemo pronaći kod Laniye (2005.). Prema Felstiner i sur. (1980./1981.) sporovi nisu zadan i statički fenomen, već se radi o društvenom procesu ovisnom o vremenskom razdoblju, socijalnom statusu sudionika te raznim drugim faktorima. Od jednog neimenovanog događaja do spora moraju proći tri transformacije: 1) imenovanje (naming) u kojem doživljaj štetan po pojedinca ili grupu mora biti prepoznat kao društveno štetan; 2) optuživanje (blaming) kada se šteta pripisuje drugoj osobi ili grupi i 3) potraživanje (claiming) odštete od onog koga se smatra počiniteljem i tek kada ta osoba/grupa odbije dati odštetu dolazi do spora. Laniya (2005.) preuzima ovaj okvir transformacije sporova kako bi opisala uznemiravanje na javnim mjestima. Prva transformacija, odnosno imenovanje, ključna je iz dvaju razloga: bez nje ni druge ne mogu uslijediti te je vjerojatno najviše ovisna o kulturnom, obrazovnom i ekonomskom statusu u kojem se nalazi onaj koji je doživio štetu i onaj koji ju je uzrokovao kao i o njihovoj socijalnoj mreži. „U kontekstu uznemiravanja na javnim mjestima, imenovanje traži artikulaciju i dijeljenje iskustava, pridavanje termina koji točno objašnjava ta iskustva, identifikaciju sa zajedničkim karakteristikama tih iskustava i njihovih posljedica te smještanje događaja u širi socijalni i politički kontekst" (Laniya, 2005.:99). No budući da se uznemiravanje rijetko događa muškarcima, oni ili ne primjećuju ovaj problem ili ga smatraju bezazlenim i nepripadajućim u područje prava (West, 2000.), pa ni ne dolazi do imenovanja problema. Proces imenovanja uključuje i prepoznavanje štete, odnosno posljedica koje uznemiravanje na javnim mjestima ima na žene. Hall (1993., prema Laniya, 2005.) također potvrđuje da je način na koji interpretiramo svijet ovisan o našim doživljajima, ali i o političkom, društvenom te ideološkom statusu. Tako će dominantna grupa (u smislu spola, rase, i seksualnosti) interpretirati neki događaj na način koji je konzistentan s njezinim vlastitim privilegiranim položajem i pogledom na stvarnost, dakle načinom koji se razlikuje od marginalizirane grupe. Radi hegemonije stvorene od dominantne grupe, marginalizirana grupa također može pristati na taj način interpretacije. Trenutno većina žrtava uznemiravanja ni ne zna da se njihovo pravo krši (prava na slobodu kretanja bez straha, privatnost). Diskrepancija iz- 
među interpretacije dominantne grupe te doživljaja i reakcije marginalizirane grupe ipak na kraju dovodi do drugačijih interpretacija stvarnosti. Tako će muškarci češće interpretirati uznemiravanje kao bezazleno ili kao kompliment jer ga vide kao izoliran događaj, dok žene češće taj fenomen interpretiraju u svjetlu drugih, sličnih, više ili manje prijetećih, ali nimalo bezazlenih iskustava (Laniya, 2005.). Rodne razlike u doživljaju uznemiravanja prikazane u ovom članku istraživali su Street i sur. (2007.) te Balenović i sur. (2000.). Neimenovanje i u skladu s time neprepoznavanje posljedica problema od dominantne grupe može se povezati s istraživanjem Balenovića i sur. (2000.) u kojem je utvrđeno da se žene i muškarci značajno razlikuju u percepciji seksualnoga uznemiravanja, tj. da žene negativnije procjenjuju takve događaje od muškaraca. Rodne razlike došle su do izražaja i u određivanju kazne za počinitelje. Žene uključene u istraživanje predlagale su strože kazne, a muškarci češće smatraju da je kazna nepotrebna, što je u skladu s njihovom blažom percepcijom seksualnoga uznemiravanja. Pronađene su i razlike između muškaraca i žena u emocionalnim i bihevioralnim reakcijama u slučaju seksualnog uznemiravanja. Blumenthal (1998.) je utvrdio da žene percipiraju širi raspon ponašanja kao uznemiravanje od muškaraca.

I odustajanje, odnosno prekid procesa može se javiti u bilo kojem momentu, ali najviše prilikom potraživanja naknade štete zbog osjećaja nemoći žrtve (Laniya, 2005.). Žrtva koja pripada manjini koja je povijesno marginalizirana i diskriminirana može odustati od suđenja jer ne vjeruje da će joj sustav koji je služio u diskriminaciji njezine grupe sada pomoći. To potvrđuje i podatak da fizičke radnice i manje obrazovane žene, koje su dvostruko marginalizirana skupina i zbog roda i zbog nižeg obrazovanja, rjeđe svjedoče o uznemiravanju i još rjeđe traže naknadu štete nego obrazovane žene (Jasperd i sur. 2001., prema Parish i sur., 2006.). Kada uznemiravanje prepoznamo kao problem, potrebno je razviti adekvatne strategije prevencije i suzbijanja. Darnell i Cook (2009.) daju preporuke za uspješniju prevenciju. Predlažu dugotrajniji preventivni rad s muškarcima tijekom kojeg se sudionike tretira kao saveznike, odnosno izravno ih se ne konfrontira i ne tretira kao počinitelje (Fabiano, Perkins, Berkowitz, Linkenbach i Stark, 2003.; Breitenbecher, 2000., prema Darnell i Cook, 2009.). Autorice navode da će muškarci biti spremniji uznemiravati žene u vršnjačkim grupama koje potiču ili podržavaju uznemiravanje, čak i ako se kad su sami ne bi tako ponašali, stoga treba iskoristiti taj vršnjački pritisak i u obrnutom smjeru (Fabiano i sur., 2003., prema Darnell i Cook, 2009.), a s tim u vezi otvara se i mogućnost pozitivnog utjecaja promatrača koji ukoliko reagiraju i osude uznemiravanje, pokazuju uznemiravateljima da to nije općeprihvaćena norma muškog ponašanja (Banyard, Moynihan i Plante, 2007., prema Darnell i Cook, 2009.).

Kearl (2010.) predlaže četiri koraka u borbi protiv uznemiravanja na javnim mjestima. Prvi se korak odnosi na prepoznavanje problema, odnosno osvještavanje da je uznemiravanje oblik nasilničkog ponašanja i diskriminacije. Drugi korak treba biti usmjeren na osnaživanje žena koje ih treba naučiti kako se obraniti, što odgovoriti i gdje mogu potražiti pomoć jer ignoriranje i izbjegavanje ništa ne rješavaju, nego samo dodatno obespravljuju žene te šalju uznemiravatelju poruku da je njegovo ponašanje prihvatljivo. Treći korak podrazumijeva usmjeravanje na potencijalne uznemiravatelje, koje je edukacijama, ali i sankcijama potrebno potaknuti na usvajanje ponašanja kojima pokazuju poštovanje prema ženama. Četvrti je korak usmjeren na 
promjenu društva i društvenih normi koje omogućavaju da se uznemiravanje na javnim mjestima dogodi. Ovaj korak uključuje i zagovaranje promjene propisa te javnih politika koje diskriminiraju žene.

\section{Zaključak}

Prikazani pregled literature pokazuje da je uznemiravanje žena na javnim mjestima učestala pojava, čak češća nego drugi oblici spolnog uznemiravanja žena, npr. spolno uznemiravanje na radnom mjestu ili u obrazovnim ustanovama (Macmillan i sur., 2000.; Lahsaeizadeh i Yousefinejad, 2012.). Autorice smatraju kako je uznemiravanje na javnim mjestima potrebno prepoznati kao oblik rodnog nasilja koji s drugim oblicima dijeli neke zajedničke karakteristike i etiologiju, ali ima i neke svoje specifičnosti. Vezano uz specifičnosti, uznemiravanje na javnim mjestima podrazumijeva počinitelje koji su ženama nepoznati, sama se viktimizacija osobito trivijalizira, često i percipira kao kompliment, te nije omogućena pravna zaštita. Istraživanja prikazana u ovom radu za uznemiravanje na javnim mjestima koriste ista teorijska objašnjenja kao i za ostale oblike rodnog nasilja, te uznemiravanje na javnim mjestima objašnjavaju putem feminističkog pristupa razlike u moći; uznemiravanje služi kako bi se održao status quo muške dominacije ili za izgradnju i održavanje rodnih uloga i normi (Laniya, 2006.; Lenton i sur., 1999.; Parish i sur., 2006.). Prikazane posljedice uključuju individualne posljedice poput negativnih osjećaja, samo-objektivizacije i umanjivanje osjećaja sigurnosti žena u javnim prostorima, dok se posljedice na društvo odnose na učvršćivanje podjele na javno - privatno, objektivizaciju žena i ograničavanje njihovog društvenog doprinosa. Prema navedenoj etiologiji i posljedicama možemo zaključiti kako uznemiravanje na javnim mjestima, kao i ostali oblici rodnog nasilja, doprinosi diskriminaciji žena, umanjuje njihovu sigurnost i sprečava njihovu punu participaciju u društvu. Unatoč tome uznemiravanje žena na javnim mjestima fenomen je koji se često ne prepoznaje kao društveni problem, već se žensko iskustvo trivijalizira i na uznemiravanje nema društvene reakcije ni sankcija za uznemiravatelje.

Autorice, uz pregled istraživanja i posljedica uznemiravanja žena, opisuju prijedloge kako prepoznati ovu pojavu kao društveni problem i pristupiti njegovoj prevenciji i suzbijanju. Za sveobuhvatan pristup prevenciji i suzbijanju uznemiravanja potrebno je uključiti i muškarce i žene te ih potaknuti da osvijeste posljedice koje uznemiravanje ima na ženu kao pojedinku, ali i na društvo u cjelini. 


\section{Literatura}

1. Balenović, T.; Hromatko, I.; Markovina, J.; Perica, V.; Paratušić, A.; Poljanić, S. (2000). Studentska percepcija seksualnog uznemiravanja. Društvena istraživanja, 50 (6): 811-827.

2. Borić R. (ur.) (2007). Pojmounik rodne terminologije prema standardima Europske Unije. Zagreb: Centar za ženske studije i Ured za ravnopravnost spolova Vlade RH. Pregledano 19. kolovoza 2011. (http://www.ured-ravnopravnost.hr/ site/preuzimanje/biblioteka-ona/pojmovnik rodni.pdf).

3. Bowman, C. G. (1993). Street harassment and the informal ghettoization of women. Harvard Law Review, 106 (3): 517-580.

4. Blumenthal, J. A. (1998). The Reasonable Women Standard: A Meta- analytic Rewiev of Gender Differences in Perceptions of Sexual Harassment. Law and Human Behaviour, 22 (1): 33-57.

5. Darnell, D. A. and Cook S. L. (2009). Investigating the utility of the film War Zone in the prevention of street harassment. Psychology of Women Quarterly, 33: 266-274.

6. di Leonardo, M. (1981). Political Economy of Street Harassment. Aegis: 51-57. Pregledano 20.rujna 2011. (http://www.stopstreetharassment.org/wp-content/ uploads/2011/04/PoliticalEconomyofStHarassment.pdf).

7. Fairchild, K. and Rudman, L. A. (2008). Everyday Stranger Harassment and Women's Objectification. Social Justice Research, 21 (3): 338-357.

8. Felstiner, W. L. F.; Abel, R. L. and Sarat, A. (1980/1981). The emergence and transformation of disputes: Naming, blaming, claiming... Law and Society Review, 15 (3/4): 631-654.

9. Gardner, C. B. (1995). Passing By: Gender and Public Harassment. Berkeley, CA: University of California Press.

10. Hunter, M. (2012). Hollaback Istanbul. Rezultati istraživanja. Pregledano 14. siječnja 2013. (http://www.ihollaback.org/wp-content/uploads/2012/06/Streetharassment-in-Istanbul.pdf).

11. Izvješća pravobraniteljice za ravnopravnost spolova za 2011., 2010. i 2009. godinu. Pregledano 20. rujna 2012. (http://www.prs.hr/index.php/izvjesca).

12. Kazneni zakon, Narodne novine 79 od 2013.

13. Kearl, H. (2010). Stop Street Harassment: Making Public Places Safe and Welcoming for Women. Santa Barbara: Praeger.

14. Kissling, E. A. (1991). Street Harassment: The Language of Sexual Terrorism. Discourse \& Society, 2 (4): 451-460.

15. Lahsaeizadeh, A. and Yousefinejad, E. (2012). Social Aspects of Women's Experiences of Sexual Harassment in Public Places in Iran. Sexuality \& Culture, 16: $17-37$.

16. Laniya, O. O. (2005). Street Smut: Gender, Media, and the Legal Power Dynamics of Street Harassment, or 'Hey Sexy' and Other Verbal Ejaculations. Columbia Journal of Gender and Law, 14 (1): 91-130.

17. Lenton, R.; Smith, M. D.; Fox, J.; Morra, N. (1999). Sexual Harassment in Public Places: Experiences of Canadian Women. Canadian Review of Sociology/Revue canadienne de sociologie, 36 (4): 517-540. 
18. Macmillan, R.; Nierobisz, A. and Welsh, S. (2000). Experiencing the Streets: Harassment and Perceptions of Safety Among Women. Journal of Research in Crime and Delinquency, 37 (3): 306-322.

19. Mamula, M. (ur.) (2006). Stanje seksualnih prava žena u Hrvatskoj - rezultati istraživanja. Zagreb: Ženska soba.

20. McEwen, L. (2013). USA: Anti-flirt club and hassle-free zones, 100 years of activism. Stop Street Harassment, SAD. Pregledano 11. travnja 2013. (http://www. stopstreetharassment.org/2013/10/shhistory/).

21. Parish, W. L.; Das, A. and Laumann, E. O. (2006). Sexual Harassment of Women in Urban China. Arch Sex Behav, 35: 411-425.

22. Perasović Cigrovski, B.; Horvat, M. i Komšić, I. (2012). Hollaback Hrvatska. Rezultati istraživanja. Pregledano 14. Siječnja 2013. (http://croatia.ihollaback.org/ podrska/istrazivanja/).

23. Roszak, J. i Gober, G. (2012). Hollaback Poljska. Rezultati istraživanja. Pregledano 14. siječnja 2013. (http://www.ihollaback.org/wp-content/uploads/2012/06/ Harassment-in-public-spaces-in-Poland_Roszak-and-Gober1.pdf).

24. Sarkar, S. (2011). Welcome, the new Agony Aunt. The Telegraph, Calcutta, India, srpanj 2011. Pregledano 20. rujna 2011. (http://www.telegraphindia. com/1110731/jsp/7days/story_14312038.jsp).

25. Street, A. E.; Gradus, J. L.; Stafford, J.; Kelly, K. (2007). Gender Differences in Experiences of Sexual Harassment. Journal of Consulting and Clinical Psychology, 75 (3): 464-474.

26. Tanasković, B. i Račeta, M. (2007). Istraživanje seksualnog uznemiravanja u javnom prevozu u Beogradu. Temida: 23-32.

27. Ustav RH, Narodne novine 85 od 2010.

28. Walkowitz, J. R. (1998). Going Public: Shopping, Street Harassment, and Street walking in Late Victorian London. Representations (62): 1-30. Pregledano 20. rujna 2011. (http://www.stopstreetharassment.org/wp-content/uploads/2011/04/ SH-victorian-london.pdf).

29. West, R. (2000). The Difference in Women's Hedonic Lives: A Phenomenological Critique of Feminist Legal Theory. Georgetown Law Faculty Publications and Other Works. Paper 573. Pregledano 20. rujna 2011. (http://scholarship.law. georgetown.edu/facpub/573).

30. Zakon o prekršajima, Narodne novine 88 od 2002.

31. Zakon o ravnopravnosti spolova, Narodne novine 82 od 2008.

32. Zakon o suzbijanju diskriminacije, Narodne novine 85 od 2008. 


\title{
Martina Horvat
}

Doctoral studies, Department of Social Work, Faculty of Law, University of Zagreb, Croatia e-mail: martinahorvat1981@yahoo.com

\section{Barbara Perasović Cigrovski}

Doctoral studies, Department of Social Work, Faculty of Law, University of Zagreb, Croatia e-mail: perasovic@gmail.com

\section{Harassment of Women in Public Places - Causes, Forms and Prevalence in Croatia and in the World}

\begin{abstract}
The article focuses on street harassment which authors define as harassment of women in public places such as streets, parks or public transport. Current researches in Croatia and in the world show that it is a widespread phenomenon and a large number of women have experienced some kind of harassment in public places. Both scientists and community activists show growing interest in this phenomenon, but it has not yet been sufficiently and adequately explored. The first objective of this paper is to define and describe the phenomenon of street harassment, as well as etiology, phenomenology and consequences of harassment. The second objective is to provide a review of the existing researches on the prevalence of street harassment in Croatia and other countries. The authors summarize researches on the incidence of street harassment, explain basic terms connected to harassment, the connection of street harassment to other forms of gender - based violence and discrimination of women and describe the individual and social consequences of street harassment. Street harassment is part of a continuum of violence against women with consequences on the individual woman's well-being and on the whole society that needs to be recognized as a social problem and a form of discrimination.
\end{abstract}

Key words: street harassment, sexual harassment, gender - based violence. 